\title{
Boys Do Cry: Epistemologies of a Pronoun
}

\section{JEAN NobLe}

Jean (Bobby) Noble is an Assistant Professor at York University,

Toronto, where s/he teaches English and Cultural Studies.

$\mathrm{I}^{\mathrm{n}}$

n his review of Boys Don't Cry, J. Hoberman writes:

Coproduced by the tireless Christine Vachon, Boys Don't

Cry has a family resemblance to I Shot Andy Warhol, which she produced in 1996. Like the Warhol film, Boys Don't $C r y$ is a polished first feature, ripped from the headlines and constructed around a stellar stunt performance. More crucially, both movies are intelligently glamorous evocations of sexual insurrection. But where Valerie Solanas the antiheroine of I Shot Andy Warhol was her own ideologue, the surreal being at the heart of Boys Don't Cry left no text behind. ${ }^{1}$

The understated but very successful film Boys Don't Cry - by firsttime director and Columbia University film student Kimberly Peirce - won not only critical acclaim but mass media attention when lead actress Hilary Swank won an Academy Award. In an instant Swank became "a household name ... and the toast of the town as one of the most acclaimed actresses of the year" (Hoberman, n.p.). On the night of the 2000 Academy Awards, female masculinity, the events of December 31, 1993, in Falls City, Nebraska, and the dynamic duo of Swank and Peirce took center stage. "We have arrived!" was the

${ }^{1}$ Both I Shot Andy Warhol and Boys Don't Cry were produced by the production company Killer Films Productions.

torquere: Journal of the Canadian Lesbian and Gay Studies Association I Revue de la Société canadienne des études lesbiennes et gaies

Vol. 3 (2001) @ CLGSA / SCELG 
banner email on one transgender / transsexual listserv the next morning.

Such an arrival makes Hoberman's assertion that "the surreal being at the heart of this film left no text behind" even more ironic. Disregarding the adjective "surreal," there is not an absence of text about this being but rather a wild proliferation of discourse, an excess of texts. In fact, there are so many competing, contradictory, and sometimes acrimonious texts that they confound my attempts to avoid those discourses by - at least temporarily - not naming the subject. To name this subject is to hail it into subjectivity and discourse. But naming can also enable closure and summary. To refer to our subject as "he, Brandon Teena" is surely to evoke one text: Brandon as a boy, as a heterosexual boy. This assignation is dramatically different from "she, Teena Brandon" - lesbian passing as a boy - or "s/he, Teena Brandon" - butch dyke - or "he, Billy Teena" - the "trailerpark Romeo" - all actual names that this subject used at different times in his and/or her short life. Each of these names and accompanying pronouns traces knowledge production and discursive operations that invest gendered subjectivities with contradictory currency. In this essay, I explore Swank's performance as Brandon as well as the dialogic utterances in the film, which locate Brandon in what critics have called the borderland between butch masculinity and transsexual masculinity. Arguing that the film itself is a formal transfiction, where fiction and documentary have been blurred, I similarly argue that the trans subjectivities in the film, that is, the fictionalized Brandon and Lana, exist in a no man's land between butch/femme, heterosexuality, and transidentities, and remain productively nonrepresentable through conventional pronouns. Moreover, I also argue that the identities of both characters shift dramatically in this film, which is as much about working-class whiteness as it is about gender subjectivity. Finally, I conclude that the shifting subjectivities in Boys Don't Cry reflect the articulated lesbian desires of its filmmaker.

In her acceptance speech at the Academy Awards, Hilary Swank made an important intervention in these operations by eulogizing the political text and subjectivity she thinks our subject left behind: "And last, but certainly not least, I want to thank Brandon Teena for being

${ }^{272} 2^{\text {nd }}$ Academy Awards, 26 March 2000. Complete text of acceptance speech available at www.oscars.org. 
such an inspiration to us all. His legacy lives on through our movie to remind us to always be ourselves, to follow our hearts, to not conform. I pray for the day when we not only accept our differences, but we actually celebrate our diversity." Swank was, of course, acknowledging the price Brandon paid for bequeathing that legacy. By the end of the week immediately following the Academy Awards, Swank was sharply criticized by Brandon's mother for using male pronouns to refer to Brandon. Swank quickly responded to her criticism by issuing a public apology to Brandon's family for supposedly "misrepresenting" him by using a masculine pronoun ("Entertainment").

Confusions over Brandon also emerge elsewhere. A recent A\&E American Justice minidocumentary titled The Life and Death of Teena Brandon includes an interview with one member of the jury that convicted Tom Nissen and John Lotter for murdering Brandon. The juror talked about the profound confusions caused by the lack of stable referent. To be specific, that juror discussed the ways that the shifting pronouns in the courtroom almost resulted in a "hung jury." Many times the jury had to stop the proceedings to ask for clarification about who was actually being referenced by the pronouns. In the film Boys Don't Cry, this kind of heteroglossia plays out in different ways. $^{3}$ In an early scene, for example, Brandon, who is already passing as male, defends a potential love interest against the unwanted advances of a very large man in a bar. Seconds before he throws the first punch at Brandon, the man yells, "you got to be kidding you little fag." The confused and confusing epithet marks Brandon as a site where queer identities, unbeknownst to the characters in the narrative, come full circle seemingly back to a dialogic heterosexuality and its perceived failures: that is, it marks Brandon's success at creating a verisimilitude of soft heterosexual masculinity, an identity overdetermined as failed masculinity.

The destabilized and destabilizing pronoun referents of any conversation about Brandon reveal the complexities of the texts that Brandon left behind and the challenges that those texts create for the relationships between language, subjectivities, and bodies. As border wars, they demonstrate the overdetermined link between narrative

${ }^{3}$ Heteroglossia is the term created by Mikhail Bakhtin to describe 'different tongues,' or the presence of more than one voice in any given narrative. See Bakhtin's essay "Discourses in the Novel." 
and truth. Numerous filmmakers are seeking to present different versions of Brandon's narrative. These versions compete not only for ownership of the dead but also for the means of reproducing the so-called truth about Brandon (Hale). The makers of the video The Brandon Teena Story - Susan Muska and Greta Olafsdottir - fight with Peirce in The Advocate over who has told the 'real' story of Brandon. Muska and Olafsdottir claim the rival Boys Don't Cry lacks a moral point of view and a political critique of what happened to Brandon. As it turns out, Muska and Olafsdottir themselves had sold the rights to their documentary to Hollywood producer Don Murphy, a project also eclipsed by Peirce's film. Apparently they are not pleased with the success of Boys Don't Cry (Glitz).

Similarly, Peirce is not without controversy. Currently her work is drawing legal protests both from people whose lives and real names she uses in the film and from Aphrodite Jones, a journalist who wrote a nonfiction book about Brandon's life and death and who claims she owns the "life rights" of the major characters in the narrative. Jones owns the legal right to tell the working-class stories of the Brandon family, the Tisdel sisters and the other major players in the story of Brandon's life and death. If Jones does not get paid first, no one can be paid, including not only the actors in Boys Don't Cry but also, for instance, the Tisdel sisters, who signed story rights over to Jones. Despite the class-based glaze of this story evident in descriptors like "Romeo and Juliet in a trailer-park," the ownership of these life stories inflects this situation with class politics right from the start (Ebert). While Jones's book was the first, she paid for her rights in an economy where it seemed no one would be concerned about what happened in Falls City, where working-class lives are measured in dollar-values all the time. The former sentiment proved wrong, but, as I discuss later and in more detail, the latter remains profoundly and ironically accurate.

The recent disputes over Brandon Teena's textuality situate Brandon and female masculinity discursively within no man's land where authentic masculinity is under dispute and where the supposedly self-evident relation between male subjectivity, physicality, and power is contested. Moreover, the no man's land of this film is one where identities change: Brandon is boy, transsexual boy, and lesbian boy all at the same time. Such slippage between these identities is not one I necessarily endorse nor am I arguing that 
such indeterminacy is prescriptively always the case. Rather, this slippage is the effect of indeterminate signifiers as well as of the filmmaker's articulated lesbian desires. I shall articulate a number of ideas with the concept of no man's land in this essay. First, in no man's land the relation between lesbian masculinity, transsexual masculinity, and male masculinity is discursive and each subject only temporarily secures meaning by evoking and then repudiating one of the others. Second, I explore a relation between whiteness and class by recalling that three people were killed in a farmhouse on December 31, 1993: Brandon Teena, Candace Lambert, and Phillip DeVine, a young black man who was a lover of Lana Tisdel's sister Leslie. DeVine's death is not depicted in Boys Don't Cry. While the film is a semifictional account of the events, it remains important to theorize this racial occlusion in no man's land and secure it within the operations of white supremacy. Finally, I shall return briefly to the question that haunts any investigation of female masculinity - that is, the ways in which questions of ontology are always already overdetermined by a definitional anxiety around femininity and, in the case of female masculinity, with femme. Where female masculinity is supposedly self-evident based on visual signifiers, femininity or fem(me)ininity is supposedly indeterminate in terms of sexual orientation. ${ }^{4}$ Boys Don't Cry inverts that arrangement and how we read Brandon's masculinity - either as lesbian or transsexual - is overdetermined by the ways in which we read the character Lana (see Duggan/McHugh). During the course of Lana Tisdel's metaphorical stay in the no man's land of Boys Don't Cry, her own identity slides from heterosexual teenager to queer femme and finally to lesbian, a trajectory mapped through productive (mis)readings of Brandon's body. To name the film's subjects with even the smallest and apparently most self-evident signifiers available in language that is, with a pronoun - is to overdetermine that subject as text, as subjectivity, in discourse.

Operations of language both rely on, yet resist, and claim, yet refuse, subjectivity at the moment of its most profound, yet most

${ }^{4}$ In their manifesto, Lisa Duggan and Kathleen McHugh write "fem(me)ininity" instead of femme or femininity to show lines of alliance across femininities, to centralize femme in femininity, and to foreground the pronoun "me" in femininity in order to refuse the stereotypically self-negating feminine subject presumed to be at the core of femininity. 


\section{2 / Noble}

productive, derisions - something that began with late nineteenthcentury sexology. Hoberman's assertion notwithstanding, Brandon functions as a metatext, always already overdetermined as text but, at the same time, putting that text into crisis. Once named, each pronoun-as-signifier (that is, "he, Brandon Teena" or "she, Teena Brandon") does at least two kinds of cultural work. Each functions as the fruition and limit of the discourses underwriting the sex/gender system. But each also radically interrupts those discourses - an interruption that signals the entry into the mainstream of subcultural identities and categories. This entrance is marked by a nonlinear temporality and by a parasitic deconstructive series of operations that illustrate Bakhtin's assertion that "when one finds a word, one finds it already inhabited ... every thought, feeling, and experience must be refracted through the medium of someone else's discourse, someone else's style, someone else's manner [so much so that] almost no word is without its intense sideward glance at someone else's" ("Discourse in Dostoevsky" 202-03). While that occupation of language in no man's land proved fatal for Brandon, it provides important texts both to think and to unthink.

But let me up the ante on these discursive battles. If, in no man's land, we can no longer use the body as a foundational guarantor of gender, and if we can no longer measure the former by the latter, or vice versa, then what secures the other performances of gender that are the secondary effects of that supposed foundation - identities such as lesbian, butch, femme, heterosexual? What is it that might distinguish lesbian from woman, transsexual masculinity from butch masculinity, transsexual man from biologically born boy, lesbian femininity from heterosexual femininity? Performances of masculinity in Boys Don't Cry - femme and otherwise - foreground its many registers. Eve Kosofsky Sedgwick names these registers threshold effects, places where incremental movement along one dimension (say, for instance, Brandon as a butch lesbian) suddenly appears as a variable on an entirely different dimension (Brandon as a heterosexual boy) (16). In terms of gender, Sedgwick advises, it is sometimes necessary to cross over the threshold of one thing (lesbian masculinity), or flip its switch from on to off, in order to register on another scale completely (heterosexual masculinity). In her performance of female masculinity in Boys Don't Cry, Swank accomplishes 'realness effects' akin to those of the drag kings who 
create an illusion or simulacrum of a reality that is better or more real than the so-called original (see Butler). Part of the surprise of her performance is that it accomplishes this without the 'layering' that often helps drag kings to achieve verisimilitude. Judith Halberstam suggests drag king performances are particularly effective because, while performing, the persona of the king is layered on top of an already existing offstage masculinity that adds depth and texture to the performance. ${ }^{5}$ Unlike many - but not all - drag kings, Swank seems to identify as female and feminine. She had to find her way onto a map of masculinity, ${ }^{6}$ then enter a portal to female masculinity, and then 'switch off' in order to register as simply masculine. In other words, the rheostat that might adjust the seamless gradations from femininity to female masculinity to - in this case - heterosexual masculinity ("man") seemingly had to be interrupted by the on/off switch of woman first, lesbian second (see Sedgwick 18).

If, as I have been arguing, the body is not the stabilizer of gender, then what is? Bakhtin, Sedgwick, Judith Butler, Stuart Hall, and many others might agree that one of the most frequently used stabilizers of gender is discourse and, specifically, narrative. Subjects either recognize or misrecognize themselves in femininities and masculinities that constitute them and that they, in turn, rearticulate (Sedgwick 19). In an undergraduate English course at York University called "Recent Women's Fiction," I taught Rose Tremain's novel Sacred Country, which like Boys Don't Cry also deals with a subject on the " " " between lesbian masculinity and transsexual masculinity. In the class on Tremain's text, I posed two questions to my students: 1. "Would you be able to recognize yourself if you were not your

SFor instance, Dirk Diggler, one of Toronto's most talented drag kings, also does a skilful parody of the Canadian singer Anne Murray. What makes "M/ann Murray" so textured is Dirk's hypermasculine gender persona that clearly leaks through when Dirk is wearing a dress and performing as M/ann Murray, foregrounding and exaggerating the hint of masculinity that has always haunted Anne Murray's gender performance.

${ }^{6}$ One of the things that marks Swank's performance of masculinity as realistic but that confuses "Hilary" and "Brandon" in the service of antitransphobic and antihomophobic agenda is the fact that she prepared for the role by passing as a boy in her personal life. Interviews with Swank focus on how she borrowed her husband's clothing and accompanied him to social events as Hilary's brother. Swank also talks about losing weight to make her body seem more boyish but she also recalls how difficult it was to find a hairstylist who would cut her apparently long hair into a boyish style, something that a number simply refused to do (BeatboxBetty). 


\section{4 / Noble}

gender?" and 2. "How do you know you are your gender?" One of the more insightful answers was: "Identity is like an image of yourself that you want to move towards ... My immediate response to the question was, well, I know I'm a girl 'cause I know that I want to be a girl, and it's constant working towards that image of what I want to be, while recognizing it as a desire, not a stable core."7 Clearly this particular answer is informed by the work of Butler who argues that a morphological imaginary overdetermines and mediates gendered subjectivity. In both Gender Trouble and Bodies That Matter, Butler contests the self-evidence of the "sex" that supposedly underlies the social constructedness of gender, arguing that the materiality of the body is formed through its triangulations with the social and discursive world via the psyche. In fact, Butler goes on to suggest that it is "important to think about how and to what end bodies are constructed ... and ... [which] bodies are not constructed and, further, to ask after how bodies which fail to materialize provide the necessary outside, if not the necessary support, for the bodies which, in materializing the norm, qualify as bodies that matter" (Bodies 16). In Boys Don't Cry, an imaginary construction of the boy mediates Brandon's relationship to his identity; while he cannot fully materialize as that boy, he most certainly reiterates and qualifies that discursive construction of masculinity. Brandon recognizes himself as a boy through a productive set of negations that allow that necessary outside to materialize, albeit very contingently: "I'm not a dyke," which also means "I am not a woman." As we proceed to watch him watch himself (and that morphological imaginary) in mirrors, combing his hair in a more masculine way, binding his breasts and stuffing his pants on two different occasions with a pair of socks, we read him moving toward that image he has of himself and his paradoxical and unthinkable gender. Not only does a dynamic of self-recognition or misrecognition articulate the meeting place of discourse, subjectivity, and physicality, but that dynamic is only knowable as and through those articulations. One of the heady pleasures of Boys Don't Cry lies in watching Brandon elaborate that fantasy of himself as a boy; that pleasure is equaled later by devastation as the camera's gaze is complicit with the shattering of that fantasy.

${ }^{7}$ Shauna Lancit. "Recent Women's Fiction.” York University, Toronto. 29 March 1999. Used with permission. 
One of the most telling and nonverbal articulations in Boys Don't Cry occurs in and around the stylization and recognition of Brandon's hair as masculine. The necessity of a masculine haircut resonates from the opening words of the movie to the final murder scene; in many ways, the style of Brandon's hair constructs part of the newly emerging cultural identity of 'boy.' While there tends to be a somewhat disturbing uniformity among the subjects of femininity in the film (Candace, Kate, the character Lana, and Lana's mother), masculinity ranges from the stereotypical constructions of workingclass men as drunken truckers (the first trucker Brandon fights with), as rough, violent rednecks such as Nissen, Lotter, and the boys who chase Brandon through the trailerpark yelling "dyke" and "faggot," or as inept law enforcement officers such as Sheriff Laux, to Brandon, the teenage, nonphallic, sweet, good-looking, charming 'boy' with small hands, good hair, a tidy appearance, one who, above all, treats women with respect. In his essay "Why Boys are Not Men," Steven Cohan theorizes the distinction between "men" and "boys" through a genealogy of Hollywood male stars. Tracing the emergence of what John Wayne dubbed the "trembling, torn T-shirt types"-Marlon Brandon, Montgomery Clift, James Dean, Sal Mineo, the young Paul Newman, etc. - through the postwar era, Cohan posits that Hollywood crystallized a new male subjectivity. "One has only to recall," argues Cohan, "the galvanizing early screen appearances of the young Brando and Clift to see how readily imagery of a youthful male body, not only beautiful to behold but also highly theatricalized, marked out the erotic appeal of these new young actors within the star system, underscoring their alienation from the screen's more traditional representations of masculinity" (203). What appealed to mainstream American culture was precisely the trope of boyishness. Such a new look challenged the conflation of sexuality and gender that underwrites a symbolic economy in which 'boys' were made legible opposites of 'men.' The result of this open rejection of hegemonic norms, according to Cohan, was an erotic performance or impersonation that productively fell short of the original.

Moreover, what was particularly compelling about the boy was signaled by Wayne's adjective "trembling." The term rightly suggested a conflation of that 'new look' with an emotionality and vulnerability. Where old-guard actors like John Wayne embodied virility and hypermasculine hegemony, stars like Brando and Dean 
interiorized masculinity, converting social nonconformity and rebelliousness into inner torment and emotional excess (Cohan 203). Where Wayne-esqe Hollywood he-men wore masculinity on the outside as action, phallic power, and mobility, the Brando and Dean types resisted such exteriorization of masculinity in favor of a look synonymous with failed manhood: perpetual boyhood. The boy, then, is a dialogic and gender-conflicted concept that at once signifies and exceeds masculinity. Citing cultural critic Marjorie Garber, Cohan likens the effect of the boy to that of a transvestite, that subject who crosses gender boundaries and calls categories into question. Elaborating upon this so-called "feminization" of the virile Hollywood star, Cohan argues that the boy similarly passes between binarized categories, disturbing the ease with which Hollywood's men equated sexual potency with hypermasculine gender performances (260).

Peirce and Swank's portrayal of Brandon in Boys Don't Cry both relies on and outs the queerness of the dialogic Hollywood boy. Rather than suggest that the boy is comparable to the transvestite in effect, it is much more productive to query the signifiers of sexuality investing the boy instead. Part of the appeal of boyishness, as Kevin Studlar and Gaylyn Sandler posit, is that feminization (9). Boyishness both holds the promise of phallic power and resists its hegemonic and teleological imperatives. In other words, the appeal of the boy is not necessarily a confusion of gender, but the potential for actualization of that gender. Boys paradoxically threaten to become men while categorically rarely materializing that identity. Peirce herself locates Brandon as a boy within this noisy dialogism of Hollywood's no man's land:

in addition to representing a queer archetype, Brandon actually embodied many traits of the traditional Hollywood hero. He had the innocence and the tenderness of Montgomery Clift in Red River or a young Henry Fonda, the naive determination of Jimmy Stewart. He was a rebellious outsider like James Dean, a shy, courtly gentleman like Gary Cooper ... Bringing Brandon to Hollywood was like bringing him home. (Glitz)

Such a precise reading of Brandon situates him within the realms of those historical performances and within contemporary dialogic reiterations of that genealogy, evident in the 'new' new boys of culture: Leonardo DiCaprio or the numerous boy bands. These objects of 
teenage girl fandom and consumption are sexualized through a feminizing gaze that is seductively threatened by the very thing boys lack: phallic power (Studlar/Sandler 9).

In Boys Don't Cry, we first encounter Brandon as a voice-over saying "shorter" at the beginning of the film. When the credits stop rolling, we realize that Brandon is instructing his cousin to cut his hair even shorter. As he looks into the mirror, he continues to style his hair until he is satisfied that it looks convincingly masculine. The scene then cuts to a roller rink where Brandon, who will eventually introduce himself as Billy, is to meet a young girl named Nicole. Brandon is wearing a curious outfit as he approaches the rink doors a western shirt and a very large cowboy hat that his cousin eventually pulls off his head. Brandon attempts to pass as a country and western cowboy. ${ }^{8}$ As "Billy" walks toward Nicole, who is standing with a group of her girlfriends talking about the qualities that make up her 'dream boy,' we overhear her conversation: "Yeah, that's okay," she says, "As long as he's sweet and has good hair. That's important."

We see Brandon looking at himself repeatedly in mirrors throughout the film, continually combing and recombing his hair into a more masculine style to achieve "good hair." Brandon's sense of himself as an object of (adolescent) desire is evident in these looking relations where the camera feminizes him as a subject of nonphallic masculinity through its gaze as we watch him watching himself be watched (see Berger 46). But Brandon also possesses a masculine gaze himself. Brandon seduces Lana by watching her perform on a karaoke stage, then by chasing her around the yard of her mother's house taking Polaroid pictures of her. The film's gaze also focuses exclusively on Lana's face and breasts during their first sex scene to show the effects of the very thing Brandon is not supposed to possess - phallic power. During that scene we see Brandon have oral sex with Lana but we also see him reach into his pants just before the

\footnotetext{
${ }^{8}$ The cowboy image surrounds Brandon. Local Falls City and Lincoln newspapers reported that Brandon was buried in "men's clothing, wearing her [sic] favorite cowboy shirt and black cowboy hat." The next day a relative of Brandon's insisted that the papers print a retraction stating that Brandon was buried in "a black and white striped shirt purchased in a women's section of a local store" (Minkowitz 24). Again, such proliferating and competing narratives remind us that definitions and self-definitions are not secondary to discourse and power. They are, as Stuart Hall suggests, the sites where this struggle is engaged ("Notes" 239). They are the stakes to be won or lost in that struggle.
} 
camera cuts to Lana's face while Brandon presumably fucks her with a penis/dildo. These contradictory looking relations further the gender instabilities already present both in the film and in Brandon's identity. In the end, it is his hairstyle that most disturbs Lana, even after she has made love to him. As Lana and Brandon are planning to leave Falls City, Lana is packing her things and Brandon sneaks in through her bedroom window to help her pack. He attempts to kiss her and Lana turns away, asking, "Did you do something to your hair?" Brandon answers, "I don't know ... but I'll try to put it back," and proceeds to correct his hair in the mirror. Hairstyles in this film, especially Brandon's, function to demarcate the space of 'boy' relative to other masculinities.

Such gender instabilities are further evident in two dialogic utterances in the film: "I'm not a dyke" and "I have a sexual identity crisis." These function as double-voicing articulations, sites where stabilizing (centripetal, moving toward center) and destabilizing (centrifugal, out from center) conceptualizing impulses collide. These utterances substantiate Michel Foucault's assertion that language as discourse is productive, and Bakhtin's primary axiom that the utterance always evokes its present, past, and possible future contexts. Butler demonstrates the performative and interpellative nature of language in the forceful but almost annoying disavowal for which she is most famous: "Who or what is it that is out, made manifest and fully disclosed, when and if I reveal myself as lesbian ... To claim that this is what I am is to suggest a provisional totalization of this ' $\mathrm{I}$ ' ... such a statement presupposes that the I exceeds its determination, and even produces that very excess in and by the act which seeks to exhaust the semantic field of the 'I" ("Imitation" 18). Butler's remarks reveal that the constitutive nature of the word signifies multiple meanings and traces of its past usages, refuting yet affirming those echoes, traces, and reverberations as it inevitably relies on them. If language is the space of confrontation of differently oriented accents, then by rearticulating and 'relanguaging,' subjects reconfigure both the social context in which speech occurs and themselves as well. To repeat: these transformations are what constitute language as dialogic.

The contestation and rearticulation in language of gender variant subjectivities who exist outside of supposedly referential epistemology and linguistic systems function as touchstones for what can be identified as the noisy and dialogic condition, if not crisis, of 
language and bodies in postmodernity. That crisis of language is particularly evident in the deployment of gendered pronouns. Like Hilary Swank in her acceptance speech, I use pronouns strategically to identify tactical rearticulations of counterdiscursive subjectivities and practices that have produced new social formations. That is, if subjects are in dialogue with discourse and speak it as often as they are spoken by it, then the processes of self-articulation, which have been the object of this study and of Peirce's film, are themselves already metadiscursive. If, as S. Hall suggests, those articulations produce arbitrary unities out of contradictory elements, then the linkages between those unities can be broken ("On Postmodernism" 141). Hall's theory of articulation seeks to break the links between concepts that are the residue of opinion and custom.

Reading for articulations and disarticulations in Boys Don't Cry or any text of female masculinity can only lead inevitably to the question of how the event of this movie occurred when it did. How is it that this film and its narrative are intelligible at all? What are the discursive and articular relations between Brandon's deferral "I'm not a dyke" and Brandon's confession to Sheriff Laux that he has a "sexual identity crisis"? Does one of these utterances secure the other and how can that summary be secured, especially in no man's land? Are butch and female-to-male transsexuality as much at odds with each other in no man's land as transsexual boy and biologically born masculinity? Does 'butch' capitalize on the failed successes of 'lesbian' as performative, disavowed, and repudiated masculinity so thoroughly as to constitute it as a necessary absence?

Barbara Johnson anticipated such paradoxical questions when she wrote on the failure of success:

If the deconstructive impulse [of female masculinity or queer theory or transsexual theory or performativity] is to retain its vital and subversive edge, we must become ignorant of it again and again. It is only by forgetting what we know how to do, by setting aside the thoughts that have most changed us, that those thoughts and that knowledge can go on doing what a surprise encounter with otherness should do, that is, lay bare some hint of an ignorance one never knew one had. (16)

Boys Don't Cry performs the imperative - both pedagogical and political - of reading for productive ignorance and surprise, or reading 
for both the radical instabilities and yet political imperatives of the body and, in this case, its death, as an object of ignorance. By 'ignorance' I refer again to Johnson who argues that to read for ignorance means to read to 'unknow,' "to become conscious of the fact that what one thinks is knowledge is really an array of received ideas, prejudices and opinions - a way of not knowing that one does not know. Thus, the question is not of how to transmit but of how to suspend knowledge" (84-85). Boys Don't Cry shows us that these identities do not preexist knowledge and truth regimes but, rather, are occlusions that are also coextensive and simultaneous with and as their means of articulation.

To articulate or attempt to know the subjects at the heart of Boys Don't Cry - that is, subjects who are off the gender map - is to theorize how they are mostly dysfunctional elements of the sex/gender systems and knowledge regimes. But it also means to read not what appears in or as a representation, but to read for the "space-off," for the blinds spots of those representations. The "space-off" is a concept borrowed from Teresa de Lauretis who poses a problem that is central to my work, that is, how to discern subjectivity in representational practices that occlude that which cannot be discerned? To frame this problematic in de Lauretis's terms: "Most of the available theories of reading, writing, sexuality, ideology, or any other cultural production are built on ... narrative of gender ... bound by the heterosexual contract" (25). The solution de Lauretis suggests is to read for the unthinkable "elsewhere."

That elsewhere is not some mythic distant past or some utopian future history: it is the elsewhere of discourse here and now, the blind spots, or the space-off, of its representations. I think of it as spaces in the margins of hegemonic discourses, social spaces carved in the interstices of institutions and in the chinks and cracks of the powerknowledge apparati. (25)

That space-off or elsewhere is the productive place within representation, especially in dialogic image-making, that is not visible in the frame but inferable from what the frame can register (26). As Peirce puts it in Boys Don't Cry, Brandon dies in Falls City, a workingclass town that Brandon's cousin tells us "isn't even on a map." Brandon dies in the space-off of American class geography and, while Peirce puts Brandon on the map by introducing this new subject into 
the field of vision of American popular culture, the costs of cartographic intelligibility are high.

As I have been suggesting, the space of identity is one site where power-knowledge regimes work. As such, it can also be a site of unknowing; a site not of the absence of knowledge but of contradictory and unstable ambiguities that render knowledge-regimes dysfunctional. The subjects of these spaces in no man's land cite and articulate authoritative sex/gender discourses to enable resistant countercitational disarticulations at the same time. To create something new, an identity or a gender supposedly not thinkable inside the sex/gender system, Brandon at once evokes and repudiates that new identity (transgender boy) onto identities (butch nonphallic masculinity and heterosexual boy) that are thinkable. Laura Doan theorizes the trope of 'grafting' in her readings of the deconstructive strategies in Jeanette Winterson's novels. Grafting is a replication process "whereby a plant, perhaps tender or uncertain, is fused into a hardier member of its strain, and so the two take advantage of each other and produce a third kind, without seed or parent" (152). The literal process of grafting is an organic reproductive process where organic matter is modified by human intervention and where a new shoot might be inserted into healthy stock from which it receives enough nourishment to generate a new entity, produced by but not reducible to either of the two constitutive elements. As a figurative trope, to graft means to insert something into, on, upon, or together, to insert or fix in or on so as to produce a vital or indissoluble union; to sew together; to attach to make a 'new' thing out of the two. As Doan suggests, this is a much more useful conceptual trope, one which allows us to acknowledge the dependence of the new thing on the other two, as it is made out of those two but is not reducible to either. As Doan puts it:

The transnatural practice of grafting does not circumvent, eliminate, or destroy the ... biological matter that produces a hybrid, and as a result the process that makes an 'other' ultimately registers the inceptive binarism as excess, as redundancy. The hybrid presupposes a biological precursor (as opposed to spontaneous regeneration), but cultural (in this case, scientific) intervention bears the responsibility for the act of creation. By becoming 'something else' in a complex interplay of interdependence from and dependence 
on its biological precursors, the hybrid denatures dominant oppositional paradigms that set one against the other and subsequently accommodates more options. (152)

I use the trope of grafting to signify two processes. The first is that identified by Doan, although I will use it as a way of thinking the manifestation of transgendered (read: differently gendered) bodies as effects of the sex/gender system in crisis and transition. The process of grafting, not as an artificial, scientific reproductive mechanism, but as self-making and reproduction simultaneously within and in excess of a heteronormative model, spawns a third hybrid sex. But this is not androgyny, a mix or blending or both so-called 'natural' genders. As Doan puts it, "the notion of hybridity resonates with doing violence to nature, which results ... in the scientific equivalent of freaks, mongrels, half-breeds and cross-breeds" (153). This is a strategy of naturally denaturalizing biological essentialisms with a "sexual politics of heterogeneity and a vision of hybridized gender constructions outside an either/or proposition" in order to naturalize "cultural oddities, monstrosities, abnormalities, and [what appear to be] conformities" (154). The trope of grafting thus allows me to argue that the gender differences and distinctions are still produced in these spaces but are deployed in transsexual and transgender discourses to entirely different ends.

The notion of grafting as opposed to crossing also allows me to think the imbrications and radical dependencies that these identities - gay, lesbian, bisexual, as well as transsexual and transgender have with each other both historically (the invert + the lesbian + the transsexual) and in the current moment when the differences between them often appear as the effect of productive and performative speech acts. "I am a boy" or "I am not a lesbian" have particular effects that may not be immediate but emerge over time. One of these productive effects is the materialization or externalization of a body normally relegated to the space-off. This differential process, which produces the fantasy of positivity, occurs through practices of self-articulation and oppositionality. Thus, the object of my project here is not only the way in which Boys Don't Cry contests the alignment of bodies, identities, and power but also the ways they contest discursive practices and force a crisis by grafting articulations and speech acts onto each other. The effect of such articular speech acts is to graft what that gender looks like by 'dysarticulating' itself through 
subjectivities similar but ultimately not reducible to those intelligible in the sex/gender system. Peirce makes Brandon intelligible by having him performatively cite authoritative discourses ("I'm not a dyke") to enable an articulation (Brandon as a man and boy) that severely incites and destabilizes masculinity, showing it as a category in crisis. But Peirce also forces this subject back into an economy where the penis is the ground of identity when she depicts Brandon's exposure with such verisimilitude.

Brandon also articulates himself through another utterance in the film, confirming S. Hall's assertion that "almost every fixed inventory will betray us" ("Notes" 235). This citation also signals the ambivalences at the core of those performatives. After the rape scene, Brandon is interviewed by Sheriff Laux, who repudiates and reiterates the violence of the rape by blaming Brandon and berating him with questions about his gender. Brandon knows that he will not be taken seriously if he cannot make himself intelligible. This ritualized and coerced self-accounting is where the production of the unrepresentable, the unspeakable, and the unintelligible is most articulated with and as social abjection. At this point, Brandon says, "I have a sexual identity crisis," drawing on the clinical language and taxonomies of psychiatry to give an accounting of himself as abject. This scene is handled with great skill by Peirce for Sheriff Laux is not depicted without his own share of abjection. Yet, at the same time, Brandon's articulations are precisely the stakes to be won or lost. Once again, clinical assessment provides intelligibility, definition, and an alibi. That alibi reworks emotional and conceptual contradictions in order to clear a space of recognition and enable articulation. Hence the importance of this film and its mainstream recognition - or misrecognition - is the double-stake of containment and resistance that it makes inevitable. To recall S. Hall: popular culture is more than just one of the sites where that ambivalent struggle for and against definition is engaged; it is, in fact, the very thing to be won or lost in that struggle ("Notes" 259). In many ways, the movie's popularity suggests Brandon's admittedly contingent 'success' in that moment. ${ }^{9}$

More troubling are two other articulations that also occur in the film. In December 1993, three people were murdered in a Nebraska

'That success was compromised by the most recent legal decision on Brandon's case. In a truly bizarre ruling, on December 6, 1999, Nebraska District Judge Orville 
farmhouse: Brandon, Candace, and Phillip DeVine. Pierce's version of these events depicts only the deaths of Candace and Brandon. Peirce's occlusion of DeVine's death is a troubling whitewashing of the events. If, as I suggested earlier, gender functions as a threshold effect where movement along one axis can suddenly register on another, and that, in order to read for masculinity, we have to shut off the switch of femininity, then to read for race, and for whiteness as a race, the opposite is true. When reading whiteness as a race, it is necessary to flip the switch from off to on. That is, it becomes necessary to invert a racializing gaze, to invert what is normally hypervisible (people of color), in order to read what is everywhere but invisible: whiteness.

As a racialized identity, whiteness operates best when it cloaks itself to function not as a particular race, but as the human race, as universal mankind (see Dyer). As a 'race,' whiteness works by cloaking itself as the universal norm around which all other races, especially those marked by color, circulate and are defined. On the one hand, white domination is reproduced by the way that white subjects colonize the definitions of normal. In this regard, Brandon's death stands in as a tragedy that can signify many other tragedies, including DeVine's. To have depicted DeVine's death in Boys Don't

Coady ruled that Richardson County authorities were $14 \%$ responsible for Brandon's wrongful death by passing on the information they did to Nissen and Lotter and by not arresting them. Brandon's mother JoAnn Brandon had sought $\$ 350,000$ in a wrongful death suit against the Richardson County officials, charging that then Richardson County Sheriff Charles Laux had allowed the two men who raped Brandon on December 25, 1993, to remain at large and to go on to kill Brandon with his two friends on December 31 . The suit also charges Laux with deliberately inflicting emotional distress on Brandon while interviewing him when he reported the rape. Judge Coady awarded $\$ 86,224$ in damages and found Lotter and Nissen $85 \%$ liable for Brandon's death. Coady also ordered Laux to apologize to Brandon's family, "her" friends, and his own community for continually referring to Brandon as an "it." Brandon's "forced confession" functioned to pathologize him in front of an "expert" in order to report the crime committed against him and to be taken and treated seriously. In many ways, Brandon was unable successfully to mobilize a reverse-discourse by using the same discourses that had hailed him into subjectivity in the first place. While Leslie Feinberg, Radclyffe Hall, and Rose Tremain all allow their characters to work within and then transform the discourses that have produced them, Peirce does not. Brandon was, and remains, permanently fixed and languaged by those discourses. He is so permanently bound by these contradictions that Judge Orville Coady divided up responsibility for Brandon's death as follows: Nissen and Lotter were $85 \%$ responsible, County Sheriff Laux was $14 \%$ and Brandon himself was $1 \%$ responsible for his own death ("Brandon Teena Update" 19). 
Cry would require an explanation of the perceived intrusion of race into a film about gender and transsexuality. On the other hand, if the invisibility of whiteness colonizes the definitions of other norms, it also marks itself as a category so that the representational power of whiteness comes precisely from its belief in itself so thoroughly everywhere and everything that it fails to visually register at all. Hence, the assertion that this film is not about race, but about gender. Yet, if the house in which the murders occurred is figured as a discursive and oppositional site, DeVine's death was as much the effect of masculine rage as Brandon's was about white rage. If Peirce chose to read through one lens at a time, then it possibly makes sense not to show DeVine's death. But a multiaccentuated dialogic lens that can read for complexity will show that the subjects of that site a white working-class single mother, a black man dating a white woman, and a white transsexual man dating a white working-class girl - are all at one time or another Others that are necessary to a white masculinity that responds with rage to these apparently dysfunctional realignments of power. The fact that DeVine's death is not depicted can only be read as yet another articulation of whiteness where one identity (gender) trumps another (race) to leave whiteness invisible and naturalized.

Peirce's occlusions in the production of the film are entirely different from the kind of white class-based identities - that is, whitetrash identities - visible within the film's narrative. "White trash" refers to a hybrid intertwining of racial and class identities and foregrounds the contradictory and conflicting relations of power between those two sites. As Matt Wray and Annalee Newitz argue, white trash is a complex cultural category that both refers to actually existing white people living in (often rural) poverty and also designates a set of stereotypes and myths about poor whites (4). The expression functions to identify that which seems unnameable: a (white) race that is used to code an economic class coupled with an insult that signifies excess (trash). Race functions then to explain that which is much harder to discern: class (Wray and Newitz 8).

If race vis-à-vis DeVine's death lurks in the space-off of this film, then the symbolic location inside the film functions as a geographic and class space-off where white trash is the form of whiteness that is most visible. The class-based culture of Falls City naturalizes class differences. Most of the interior scenes in Boys Don't Cry take place 
either inside bars or in Lana's mother's house. The first time we meet the character Lana, she is in a bar, drinking, unable to stand without the help of her friends. Candace works in the bar and both girls seem to spend their leisure time drinking and singing karaoke. Lana's dream is to become a famous karaoke singer. Later in the film, the girls find employment in the canning factory, working the nightshift and continuing to drink on their days off. The viewer's first encounter with Lana's mother shows her passed out from too much alcohol. To be working-class, according to this film, means to spend a great deal of time consuming alcohol. This seems to commence with the onset of adolescence.

White masculinity in the text does not fare any better. Annalee Newitz argues that whiteness often emerges as a distinct racial identity when it can be identified as somehow primitive or inhuman. To see white as white rather than just as "another person," that white needs to be marked out as different from those whites who observe them (134). Newitz cites, for example, Hillybillyland, T. W. Williamson's study of representations of "mountain people" in Hollywood film, to argue that the figure of white-trash man is a spectacle not just because he is poor, but because he is sometimes monstrously inhuman. In Boys Don't Cry Lotter explodes into homicidal rage seemingly over nothing. Nissen lifts his pant leg to reveal self-inflicted scars from knife games that he and Lotter play. The men who are stock features in the bars of the film either aggressively harass the girls or start bar brawls. None of them are employed. Most seem single or otherwise unattached. And Nissen and Lotter come across as savagely white. After being accused of raping Brandon, Lotter replies: "If I wanted to rape someone, I have Mallory" - a female friend. The only working-class men who have jobs in Boys Don't Cry are the law enforcement officers. Sheriff Laux's treatment of Brandon easily situates him as savage and excessively brutal. The working-class whites in this film are racialized and demeaned because they fit all too easily into the primitive/civilized binary as nihilistic primitives (see Newitz 134).

One of the class-based 'characters' who, as I suggested earlier, no longer owns the right to her own story is Brandon's real-life lover Lana Tisdel. She has also filed suit against Peirce. Her chief complaints about Peirce's movie are that it puts her at the scene of the murders and shows her doing little to help afterward. Tisdel also 
claims that the final love scene in the film between the characters Lana and Brandon is a fiction that implies that she (Tisdel) is a lesbian - something she continues to deny (Beaird). Curiously, the proper name "Lana Tisdel" is a highly unstable signifier, referencing both a character in the film and the actual off-screen person. Peirce's film unwittingly follows in the same footsteps as many other twentiethcentury prose narratives about female masculinity in the sense that a reading of their work suffers from a blurring of reality and fiction, in so far as these can be separated. ${ }^{10}$ While the genre of film is different from prose narrative in terms of its articular machineries, formal properties, and contexts of consumption, Peirce's film depicts how (trans)gendered subjectivities are actualized through discourses of race and class, a materialization that foregrounds the function of the gaze in mediating bodies, subjectivities, and narratives.

In the film, Lana appears as young white trash and also as a subject of fem(me)ininity. Moreover, the film's fictionalized postrape love scene between the characters Lana and Brandon risks reconfiguring offscreen Lana as a lesbian. Despite Tisdel's objections, in the two love scenes between Brandon and Lana in the film, both subjects become their gender, not transcend it. Through these dialogic sex scenes, Boys Don't Cry severs the overdetermined linkage between queerness and masculinity by bringing fem(me)ininity into focus. The result is that Brandon's identity as "he" - transsexual boy - is not completely stable in the film. Indeed, his proximity to the character Lana and her embodiment of "she" overdetermines how we might read him as "him." However, the camera also is complicit in de- and reconstructing Brandon's identity and works against the dialogism of these scenes to contain how he should be viewed.

The first love scene between Lana and Brandon shows him operating with the very thing he is supposed to lack - that is, phallic power. The characters Brandon and Lana have sex for the first time outside, at night, on a blanket, in the dim margin of the lights from the factory. The sex scene is choreographed around Lana's pleasure so that the camera focuses on her face from above. Lana's (not

${ }^{10}$ For instance, both Radclyffe Hall's The Well of Loneliness (1928) and Leslie Feinberg's Stone Butch Blues (1993) were published to a great deal of critical attention, much of which collapsed distinctions between author and main character(s), fiction and memoir. Feinberg noted as much in a recent interview when s/he said, "I still receive letters addressed to Jess Goldberg, the fictional protagonist of my novel" (Lee 31). 
Brandon's) top and bra are off and, as mentioned above, the camera lingers on her face while Brandon performs oral sex. When Brandon enters the scene again, he is still fully clothed and remains dressed even when he fucks Lana with what is presumably a dildo. Curiously, the camera quickly flashes down Brandon's shirt, from what we are to perceive as Lana's viewpoint, to reveal a very slight cleavage. Lana seems from this point on to have an idea that Brandon's body is female, even though she later runs her hand over the bulge in his pants. However, her narration to Candace and Kate about the event tells a different story, one that reveals Lana's participation in the adolescent fantasy that Brandon builds and that she shares: "Afterward, we took our clothes off and went swimming," she tells them, infusing the narrative and its setting with a kind of pastoral and adolescent innocence.

The bulge in Brandon's pants poses an interesting epistemological and representational quandary, not unlike that of earlier twentiethcentury fiction that similarly grappled with articulating female masculinity. The invert, that creature of discursive origins who is the forebearer of both transsexual masculinity as well as lesbian masculinity, has always been and remains most productively troubling to the sex/gender system when it cannot be named with pronouns and secured within epistemological truth-regimes. Because the invert's body is not representable in language, it remains imaginable in that space just outside the frame. Since the invert's body is delegated as a body that cannot matter, what Boys Don't Cry offers is the efficacy of representational possibility. If the invert's body is not, in a productive way, a body that matters other than for what it otherwise allows to matter (i.e., conventionally gendered bodies), then Brandon's body as constructed in this film matters a great deal in and of itself. Boys Don't Cry shows the very painful way that knowledge regimes are authenticated as Brandon's phallic power is exposed and refuted. The film confirms paradoxical subject positions, especially in the disrobing scene. The fantasy gender that Brandon builds and that Lana eventually desires and shares is materialized. But that same fantasy is violently shattered when Lana and the viewer are forced to witness Brandon's body. Brandon's penis - both the simulacrum with which he fucks Lana but also the presumed one that emerges when he is passing - "works," as he says in the film, but is revealed and therefore known and recognized as fantasy. 
The second love scene occurs much later in Boys Don't Cry after Brandon has been exposed and raped and his fantasy of his body is traumatically truncated. Nissen and Lotter corner Brandon in the bathroom and tear his pants off. When Lana is forced to look at Brandon with his pants pulled down, no penis in sight, the film action stops to show what Brandon sees as he looks away from Lana: another Brandon, not harmed, standing behind Candace and Kate. This second Brandon is wearing a blue shirt and is shown as if in a mirror from the waist up. The camera then cuts to the second Brandon's gaze and shows us what he sees: the first Brandon with his pants down and his arms being held by Nissen and Lotter. The second Brandon cannot bear what he sees - his exposure - and walks away. In this intense moment, the dialogic split in Brandon between the enforced reality of his body competes and wins over the fantasy of his identity as a boy. From this moment on, his lack of penis and his rape overdetermine him as female, allowing the other characters and viewers alike to read him this way, and forcing the supposed selfevidence of matter to signify over identifactory subjectivity. The perception of Brandon's lack of an obvious penis signifies the failure of and so severely compromises his phallic articulation of himself as a (transsexual) boy. Whereas Peirce previously had the character Brandon occupy a productive place in no man's land, she now forces his subject back into an economy where the penis is the grounds of identity by depicting his exposure with such brutal verisimilitude. The second love scene attempts to assuage that violation but the events of the narrative refuse that assuagement.

After Brandon has been exposed and raped, Lana visits Brandon in the middle of the night in the shed near Candace's house where he has taken refuge. Brandon moves to rest his head on her breasts while Lana asks him, "What were you like before all this? I mean, were you like me, a girl girl?" Brandon answers, "Yeah, like a long time ago and then I guess I was just like a boy girl, and then I was just a jerk." It is curious here that both subjects can only circumvent matter and materiality in language, productively refusing to fix gender and sex. Neither can fully locate Brandon within existing pronouns and the repetition "girl girl" suggests that, by this point, Lana too is elsewhere and in excess of that signified in the sex/gender system by the singular "girl." Lana's hands continue to caress Brandon's hair and face tenderly as he confesses that many of the things he had told 


\section{$50 /$ Noble}

Lana were lies. Lana leans in and kisses Brandon, then they move as if to have sex. Lana then hesitates and says, "I don't know if I'm gonna know how to do it." Brandon replies: "I'm sure you'll figure it out."

At this point, the camera moves behind Brandon's back and Lana takes Brandon's shirt off, exposing his back to the camera. We see only his back; Lana looks at his chest. This love scene is less an attempt to reassert Brandon as female and more an attempt to construct Lana as femme. The direct suggestion of the film is that this time Lana fucks Brandon. What the viewer sees is Lana looking, touching Brandon's head and back with very fem(me)inine hands decorated with rings and long nails with bright red nail polish. Brandon as a boy is gone, that identity departing during the exposure scene where Brandon looks at a version of himself leaving. But Brandon as an oxymoronic lesbian boy nevertheless remains, still unrepresentable with pronouns and yet still signifying both masculinity and a kind of vulnerability and woundedness that requires that Lana take care of him both emotionally and sexually. Lana nurses him back into yet another version of himself. The surprise of Peirce's film is that it unwittingly brings fem(me)ininity into focus and transforms a previously unreadable image into one that is, at least contingently, visible.

This reconstruction is made possible partly because of the last twenty years of writing that has emerged out of lesbian butch-femme cultures. One of the reasons for the border war between butch and female-to-male transsexualtiy is that within the twentieth century, lesbianism has been articulated with masculinity vis-à-vis gender inversion. What we are beginning to see now is resistance to the apparent fixity of essentialist capitulation articulated through the pronoun "she." Among others, Biddy Martin has suggested that while female masculinity has been viewed as the social constructionist subject, queer femininity has always been viewed as the suspect subjectivity, "a capitulation, a swamp, something maternal, ensnared and ensnaring" (73). In fact, Martin argues that adding "femmeness" to queer theory's equations multiplies the currently unknowable permutations of sexual aims, objects, and - more specifically for my purposes here-productive heterosexual betrayals (78). Both in the film proper and apparently in its origins and production, femmeness articulates itself as a betrayal of essentialist and heteronormative 
imperatives. The character Lana chooses Brandon out of the possible range of masculine lovers available to her. And in interview after interview, Peirce herself repeatedly states that she was drawn to this story because she "fell in love with a girl who was living in a trailer park, who didn't have much money, who didn't have any role models, and yet who successfully transformed herself into a fantasy of a boy" (Glitz). In attempting to remain true to those desires, Peirce argues that the film is "an emotional artefact" of the love between the reallife Brandon and Lana. While the film is being hailed as the arrival of female-to-male transsexuality in mainstream culture, I read it as an attempt to queer Lana in order to render her more precisely an artefact of the filmmaker's investments.

Such hyperreal reiterations of the so-called facts of Brandon's death confirm that Boys Don't Cry suffers from formal confusion as a film genre. It is not a documentary, yet Peirce claims to have been true to other emotional relationships between the real-life Lana Tisdel and Brandon. Tisdel's lawsuit betrays her own anxiety and frustration over the film's verisimilitude, claiming Peirce misrepresented basic facts. But Peirce relied on many textual accounts of Brandon's death in the media - many of them sensational - to graft this hybrid film narrative from those accounts and her own interviews with the main characters in the story. As a trans- or even intergeneric, intertextual event, Boys Don't Cry is the product both of a formal and of an epistemological grafting, where one text is a hybrid of another. A new form is produced from a meeting point of two things where the new entity is not reducible to either. If gender identities are (un)knowable through a trope of grafting, then both form and content here are simulacra that stand in as the 'truth' of the events in that Nebraskan farmhouse and of the supposedly 'real-life' story of Brandon and Lana.

Peirce, Swank, and Chloë Sevigny (the actor who plays Lana) graft a seemingly new Brandon and Lana from the textual accounts of their lives, each produced from but not reducible to the media representations. Each is transformed from and through the other. That is, each is a hybrid form that does not transcend the so-called original but rather hails from and moves between its parts. Brandon's life, it seems, is entirely about text. It is a text knowable in relation to other gendered, racialized, and class-based scripts and in conversation with a history of discourses, textual practices, and their 
many articulations. Transsubjectivity emerges in the space-offs not only of discursive formations but also of pronouns. Pronouns are the washrooms of language; the practice of choosing is overdetermined by which gender one is perceived to be in any given moment. As this film makes more than apparent, the attempted precisions of language can only circumvent the no man's land between genders, narratives, discourses, and, indeed, texts and their readers. What is produced in that elsewhere is the impossible: bodies that defy matter.

\section{Works Cited}

72nd Academy Awards. NBC-TV, Toronto, 26 Mar. 2000.

Bakhtin, Mikhail M. "Discourse in Dostoevsky." Problems of Dostoevsky's Poetics. Manchester: Manchester University Press, 1984. 181-269.

- "Discourse in the Novel." The Dialogic Imagination. Ed. Michael Holquist. Trans. Caryl Emerson and Michael Holquist. Austin: University of Texas Press, 1981. 259-422.

Beaird, Joe. "Film About Famed Murder Sparks Controversy and Lawsuits." APB Celebrity News. 1 Nov. 1999. <http:// www.APBnews.com>.

BeatboxBetty. "Interview with Hilary Swank." <http:// www.beatboxbetty.com>.

Berger, John. Ways of Seeing. London: Penguin, 1972.

"Brandon Teena Update." FTM International Newsletter 46 (2000): 19.

Butler, Judith. Bodies That Matter: On the Discursive Limits of "Sex". New York: Routledge, 1993.

- "Imitation and Gender Insubordination." Inside/Out: Lesbian Theories, Gay Theories. Ed. Diana Fuss. New York: Routledge, 1991. 1-31.

Cohan, Steven. Masked Men. Bloomington: Indiana University Press, 1997.

De Lauretis, Teresa. "The Technology of Gender." Technologies of Gender: Essays on Theory, Film, and Fiction. Bloomington: Indiana University Press, 1987. 1-30.

Doan, Laura. "Jeanette Winterson's Sexing the Postmodern." The Lesbian Postmodern. Ed. Laura Doan. New York: Columbia University Press, 1994. 137-55. 
Duggan, Lisa and Kathleen McHugh. "A Fem(me)inist Manifesto." Women and Performance: A Journal of Feminist Theory 8 (1996): 153-59.

Dyer, Richard. "White." Screen 29 (1988): 44-64.

Ebert, Roger. Chicago Sun-Times 15 Sept. 1999: n.p.

"Entertainment." Toronto Star 2 April 2000: n.p.

Feinberg, Leslie. Stone Butch Blues: A Novel. Ithaca, New York: Firebrand, 1993.

Foucault, Michel. The History of Sexuality. Volume 1. Trans. Robert Hurley. New York: Vintage, 1978.

Glitz, Michael. "Brandon Goes to Hollywood." The Advocate. 28 Mar. 2000. <http://www.theeadvocate.com>.

Halberstam, Judith. Female Masculinity. Durham: Duke University Press, 1998.

Hale, C. Jacob. "Consuming the Living, Dis(re)remembering the Dead in the Butch/FTM Borderlands." GLQ (1998): 311-48.

Hall, Radclyffe. The Well of Loneliness. New York: Avon, 1928. Hall, Stuart. "On Postmodernism and Articulation." Stuart Hall: Critical Dialogues in Cultural Studies. Eds. David Morley and Kuan-Hsing Chen. London: Routledge, 1996. 131-50.

- "Notes of Deconstruction 'The Popular." People's History and Socialist Theory. Ed. Raphael Samuel. London: Routledge, 1981. 227-40.

Hoberman, J. “Oscars!” Hollywood.com. $1999<$ http:// www.hollywood.com>.

Johnson, Barbara. A World of Difference. Baltimore: Johns Hopkins University Press, 1987.

Jones, Aphrodite. All She Ever Wanted. New York: Pocket, 1996.

Lee, Gretchen. "Pink and Blue: Interview with Leslie Feinberg." Curve 8 (1998): 31.

The Life and Death of Teena Brandon. [Videorecording for A \& E American Justice.] New York: A \& E Television Networks, 1996. Martin, Biddy. Femininity Played Straight: The Significance of Being Lesbian. New York: Routledge, 1996.

Minkowitz, Donna. "Love Hurts." Village Voice 19 Apr. 1994: 2430.

Muska, Susan and Greta Olafsdottir. "Reel Nebraska." The Advocate. 28 Mar. 2000. <http://www.theadvocate.com>.

—. Brandon Teena Story. Videorecording. Zeitgeist Film, 1998. 


\section{4 / Noble}

Newitz, Annalee. "White Savagery and Humiliation, or A New Racial Consciousness in the Media." White Trash: Race and Class in America. Eds. Matt Wray and Annalee Newitz. New York: Routledge, 1997. 131-54.

Peirce, Kimberly, dir. Boys Don't Cry. Videorecording. Twentieth Century Fox Home Entertainment, 1999.

Sedgwick, Eve Kosofsky. "Gosh, Boy George, You Must Be Awfully Secure in Your Masculinity!" Constructing Masculinity. Eds. Maurice Berger, Brian Wallis, and Simon Watson. New York: Routledge, 1995. 11-20.

Studlar, Kevin S. and Gaylyn Sandler. "Introduction: The Seductive Waters of James Cameron's Film Phenomenon." Titanic: Anatomy of a Blockbuster. Eds. Kevin S. Studlar and Gaylyn Sandler. New Jersey: Rutgers University Press, 1999. 1-13.

Tremain, Rose. Sacred Country. London: Hodder and Stoughton, 1992.

Williamson, J. W. Hillybillyland. Chapel Hill: University of North Carolina Press, 1995.

Wray, Matt and Annalee Newitz, eds. White Trash: Race and Class in America. New York: Routledge, 1997. 